\author{
Asian Journal of \\ Medical and Biological Research \\ ISSN 2411-4472 (Print) 2412-5571 (Online) \\ www.ebupress.com/journal/ajmbr
}

\title{
Article \\ Antimicrobial activity of some medicinal plant extracts against Gram positive and Gram negative bacteria in Bangladesh
}

\author{
Md. Mizanur Rahman, Md. Raquib Shahriar, Nigar Sultana Meghla*, Tasneema Ishika, Pravas Chandra Roy \\ and Md. Kamruzzaman \\ Department of Microbiology, Jessore University of Science \& Technology, Jessore-7408, Bangladesh \\ *Corresponding author: Nigar Sultana Meghla, Department of Microbiology, Jessore University of Science \& \\ Technology, Jessore-7408, Bangladesh. Phone: +8801816188197; E-mail: nsultana79@yahoo.com
}

Received: 20 November 2017/Accepted: 04 December 2017/ Published: 28 December 2017

\begin{abstract}
Antibacterial active compounds isolated from higher plants appear to be one of the most important alternative approaches to contain antibiotic resistance and the management of disease. The present study was aimed at to investigate the antibacterial activity of some medicinal plant species including seeds namely Centella asiatica, Oxalis corniculata, Phoenix dactylifera, Clitoria ternatea and Nigella sativa. The methanolic and ethanolic extract of Centella asiatica, Oxalis corniculata, Phoenix dactylifera and Clitoria ternatea was investigated for antimicrobial activity at different concentrations by using disc diffusion method against some bacterial strains with standard antibiotic cephachlore $(10 \mu \mathrm{g})$. The result demonstrated that all the extracts showed antibacterial activities against the isolates, which were dose dependent. The ethanolic extract of Oxalis corniculata at a concentration of $50 \mu \mathrm{1} /$ disc had the highest effect on the test organism B. subtilis, Salmonella typhi and E. coli with 9.3, 9.7 and $10.8 \mathrm{~mm}$ diameter of zone of inhibition respectively while at the same concentration the extract of Clitoria ternatea had a higher antimicrobial activity on Bacillus cereus with 11.3 $\mathrm{mm}$ diameter of zone of inhibition. The activities of the plant extracts on the tested pathogens were not as effective as the standard commercial antibacterial disc but was significant. In case of Nigella sativa, Pseudomonas aeruginosa was sensitive to both the ethanolic extract and oils at different concentration. Salmonella typhi shows the same degree of inhibition for ethanolic extract as Bacillus cereus, but greater inhibition for oils. Of all the bacteria, Pseudomonas aeruginosa was the most sensitive bacteria against ethanolic extract and oils, while Bacillus cereus was the most resistant bacteria. Generally, the oils of Nigella sativa sample had higher antibacterial activity against bacteria than ethanolic extract. All the extracts are inhibitory to most common human pathogen S. typhi. The results suggest that the different plant extracts has a significant scope to develop a novel broad spectrum of antibacterial herbal formulations.
\end{abstract}

Keywords: medicinal plant; antimicrobial activity; Gram positive bacteria; Gram negative bacteria; zone of inhibition

\section{Introduction}

Nature has bestowed on us a very rich botanical wealth and diverse types of plants grow in different parts of the world. The use of plants and plant products as medicines could be traced as far back as the beginning of human civilization (Ahmed et al., 1998). The development of drug resistance in human pathogens against commonly used antibiotics has necessitated a search for new antimicrobial substances from other sources. Several reports are available on the antimicrobial activity of plant extracts on human pathogenic bacteria (Raghavendra et al., 2006; Babu et al., 2007).

Many higher plants accumulate wide array of bioactive molecules that is extractable organic substances in quantities sufficient to be economically useful as antibiotic evolved as chemical defense against predation or infection. Generally species of higher plants are much less surveyed for antibacterial activity. It is estimated that 
only one percent of 2, 65,000 flowering plants on earth have been studied exhaustively for their chemical composition and medicinal value (Cox and Balick, 1994). Herbs are widely exploited in the traditional medicine and their curative potentials are well documented in India and other subcontinents. Plants grown in this region are not systematically tested for their biological activities in general and antimicrobial activity in particular. Alternatives to available antibiotics for disease management are increasingly felt due to the increase in the resistance of bacterial isolates. This has necessitated the requirement of second and third line drug (Williams and Heyamnn, 1998). It is believed that plant based drugs cause less or no side effect when compared with synthetic antibiotics (Shariff et al., 2006). Despite tremendous progress in human medicines, infectious diseases caused by bacteria, fungi, viruses and parasites are still a major threat to public health and particularly large in developing countries due to relative unavailability of medicines and the emergence of widespread drug resistance (Zampini et al., 2009). Recently, the World Health Organization reports that at least 75 - 95\% of the world populations of developing countries were chiefly relies on traditional medicines and major part of traditional therapies involves the use of plant extract products or their active constituents. Traditional medicine usage is a common practice in developed and developing countries at the primary healthcare level (Essawi and Srour, 2000).

Bangladesh owing to its favorable climatic influences has been blessed with immense natural resources including explored and unexplored herbal medicinal plants. About 5000 species of phanerogams and pteridophytes grow in Bangladesh. More than a thousand of these have been claimed to possess medicinal or curative properties. Recently, 546 species have been identified as having medicinal properties and therapeutic use (Ghani, 1998). In Bangladesh low income people such as farmers, people of small isolate villages and native communities use herbal medicine for the treatment of common infections. Thus the objective of this study was to evaluate the potential of phytochemicals of plant and seed extracts on several standard bacterial strains as well as multi-drug resistant bacteria.

\section{Materials and Methods}

\subsection{Sample collection}

Leaf of Centella asiatica L. (Locally known as Thankuni) was collected from borobazar, Jessore sadar, Jessore, Bangladesh on November, 2013. Leaf of Oxalis corniculata L. (Locally known as Amrul) and Seed of Clitoria ternatea L. (Locally known as Oporajita) was collected from Jessore University of Science \& Technology campus, Jessore-7480, Bangladesh on November, 2013. Fruit of Phoenix dactylifera L. (Locally known as Khejur) was collected from local area of Sherpur, Bogra, Bangladesh on October, 2013. Nigella sativa L. (Locally known as Kalojira) seeds used in this study were collected on January, 2012 and purchased from different retail groceries in Jessore, Bangladesh.

\subsection{Preparation of plant extract}

The collected plant parts were separated from undesirable materials or plant or plant parts and were washed with water. They were sun-dried for one week. The plant parts were grinded into fine powder with the help of grinder. The powders were stored in an airtight container and kept in a cool, dark and dry place.

The powered materials were dissolved in $70 \%$ ethanol and $80 \%$ methanol; $1 \mathrm{~g}$ sample was dissolved in $10 \mathrm{ml}$ of solvent (Pandey et al., 2011). Mixtures were kept in sterilized beakers wrapped with aluminum foil to avoid evaporation and exposure to light. The beakers were then kept in dark or 3 days at room temperature accompanying occasional shaking and stirring. After 3 days, mixtures were filtered through Whatman filter paper. The filtrates obtained were evaporated and concentrated under the air of ceiling fan and in a water bath to remove alcohol present in the extract.

\subsection{Preparation of Nigella sativa ethanolic extract and Nigella sativa oils}

Ethanolic extract of the Nigella sativa seeds was prepared by simple socking $50 \mathrm{gm}$ of finely grounded powder of Nigella sativa seeds in sufficient amount of ethanol for 24 hours. After 24 hours, the extract was filtered through what Mann filter paper and the residual matter was again soaked with sufficient amount of ethanol for 24 hours. After 24 hours, the extract was filtered through Whatman filter paper and then was combined of two extract and evaporated till dryness. One hundred gram of each black cumin was ground in an omnimixer and extracted for $10 \mathrm{~h}$ in a Soxhlet extractor with $500 \mathrm{ml} \mathrm{n}$-hexan at $70^{\circ} \mathrm{C}$. The fixed oils were pooled and concentrated in a rotary evaporator, and then kept in small $(10 \mathrm{ml})$ sterile bottles under refrigerated conditions until use (Ozcan, 1998). 
2.4. Evaluation of antimicrobial activity by agar disc diffusion method

2.4.1. Inoculum preparation of test bacteria

Escherichia coli (ATCC 25923), Salmonella typhi (ATCC 14028), Bacillus cereus (ATCC 11778), Bacillus subtilis (ATCC 11774) and Pseudomonas aeruginosa test organisms were transferred to the nutrient agar (HI Media, India) slants by aseptic condition. The inoculated slants were then incubated at $37^{\circ} \mathrm{C}$ for $16-18$ hours to assure the growth of test organisms. One loopful culture from each of the slants was transferred in the test tubes with $10 \mathrm{ml}$ sterile water and mixed by vortex.

\subsubsection{Antibiogram analysis}

The antimicrobial activity of various samples was determined by agar diffusion technique (Bauer et al., 1966; Philips et al., 1991). $1 \mathrm{ml}$ inoculums of each selected organism were spread by glass spread on nutrient agar media. Paper disks soaked in 15,20 and 25 or 30,40 and $50 \mu$ of the extract, then each crude extracts were placed on the surface of nutrient agar using sterile forceps. Standard commercial antibacterial discs of cephachlore $(10 \mu \mathrm{g} / \mathrm{disk})$ were included as positive control. The culture plates were allowed to refrigerate for 2.5 $\mathrm{h}$ for pre diffusion and were then incubated at $37^{\circ} \mathrm{C}$ for $24 \mathrm{~h}$.

\subsubsection{Determination of zone of inhibition}

After $24 \mathrm{~h}$, antibacterial activity was determined by measurement of diameter zones of inhibition (mm) (against the test organisms) around each of the extracts and the antibiotics with a slide calipers (Lino et al., 2006).

\section{Results}

\subsection{Determination of antimicrobial activity of Oxalis corniculata}

Oxalis corniculata exhibited Inhibition zones of the methanolic extract at $15 \mu \mathrm{L} / \mathrm{disc}, 20 \mu \mathrm{L} / \mathrm{disc}$ and $25 \mu \mathrm{L} / \mathrm{disc}$ are $-6.2 \mathrm{~mm}, 7.3 \mathrm{~mm}$ and $9.2 \mathrm{~mm}$ respectively against $B$. subtilis; B. cereus were Resistant to all; $7 \mathrm{~mm}, 8.3 \mathrm{~mm}$ and 9.5 respectively against $S$. typhi; $9.2 \mathrm{~mm}, 10.2 \mathrm{~mm}$ and $10.5 \mathrm{~mm}$ against $E$. coli (Figure 1). The Ethanolic extract at $30 \mu \mathrm{L} /$ disc, $40 \mu \mathrm{L} /$ disc and $50 \mu \mathrm{L} /$ disc showed $-7.7 \mathrm{~mm}, 8.5 \mathrm{~mm}$ and $9.3 \mathrm{~mm}$ respectively against $B$. subtilis; $7.5 \mathrm{~mm}, 7.8 \mathrm{~mm}$ and 9.2 against $B$. cereus; $7.3 \mathrm{~mm}, 9 \mathrm{~mm}$ and $9.7 \mathrm{~mm}$ against $S$. typhi; $9.8 \mathrm{~mm}, 10.7$ $\mathrm{mm}$ and $10.8 \mathrm{~mm}$ respectively against $E$. coli. The standard antibiotic disc cephaclore at $10 \mu \mathrm{g} / \mathrm{disc}$ exhibited $19.7 \mathrm{~mm}$, Resistance, $34.7 \mathrm{~mm}$ and $26.7 \mathrm{~mm}$ respectively against four selected bacteria (Table 1).

\subsection{Determination of antimicrobial activity of Centella asiatica}

Zone of inhibition of the methanolic extract at $15 \mu \mathrm{L} / \mathrm{disc}, 20 \mu \mathrm{L} / \mathrm{disc}$ and $25 \mu \mathrm{L} / \mathrm{disc}$ are $-5.3 \mathrm{~mm}, 7.3 \mathrm{~mm}$ and $9.2 \mathrm{~mm}$ respectively against $B$. subtilis; $B$. cereus were Resistant to all; $6.2 \mathrm{~mm}, 9.3 \mathrm{~mm}$ and 9.7 respectively against $S$. typhi; $5.7 \mathrm{~mm}, 7.7 \mathrm{~mm}$ and $8.2 \mathrm{~mm}$ against E. coli. The Ethanolic extract at $30 \mu \mathrm{L} / \mathrm{disc}, 40 \mu \mathrm{L} / \mathrm{disc}$ and $50 \mu \mathrm{L} /$ disc showed $-5.8 \mathrm{~mm}, 6.5 \mathrm{~mm}$ and $7.1 \mathrm{~mm}$ respectively against $B$. subtilis; $B$. cereus were Resistant to all; $7 \mathrm{~mm}, 9.7 \mathrm{~mm}$ and $11 \mathrm{~mm}$ against $S$. typhi; $6.6 \mathrm{~mm}, 7.9 \mathrm{~mm}$ and $9 \mathrm{~mm}$ respectively against $E$. coli (Table 2).

\subsection{Determination of antimicrobial activity of Phoenix dactylifera}

Phoenix dactylifera exhibited Inhibition zones of the methanolic extract at $30 \mu \mathrm{L} / \mathrm{disc}, 40 \mu \mathrm{L} / \mathrm{disc}$ and 50 $\mu \mathrm{L} /$ disc are $-B$. subtilis were Resistant to all; $5.5 \mathrm{~mm}, 6 \mathrm{~mm}$ and $6 \mathrm{~mm}$ respectively against $B$. cereus; $7.2 \mathrm{~mm}$, $7.3 \mathrm{~mm}$ and 7.5 respectively against $S$. typhi; $6.3 \mathrm{~mm}, 7.2 \mathrm{~mm}$ and $7.4 \mathrm{~mm}$ against $E$. coli. The Ethanolic extract at $30 \mu \mathrm{L} /$ disc, $40 \mu \mathrm{L} / \mathrm{disc}$ and $50 \mu \mathrm{L} /$ disc showed-B. subtilis were Resistant to all; $6.2 \mathrm{~mm}, 7.1 \mathrm{~mm}$ and $7.6 \mathrm{~mm}$ respectively against $B$. cereus; $7.5 \mathrm{~mm}, 7.8 \mathrm{~mm}$ and 8.3 respectively against $S$. typhi; $6.6 \mathrm{~mm}, 7.9 \mathrm{~mm}$ and 8.3 mm against $E$. coli (Table 3 ).

\subsection{Determination of antimicrobial activity of Clitoria ternatea}

Phoenix dactylifera exhibited Inhibition zones of the methanolic extract at $15 \mu \mathrm{L} / \mathrm{disc}, 20 \mu \mathrm{L} / \mathrm{disc}$ and 25 $\mu \mathrm{L} / \mathrm{disc}$ are - B. subtilis were Resistant to all; $6.2 \mathrm{~mm}, 8.3 \mathrm{~mm}$ and $8.5 \mathrm{~mm}$ respectively against $B$. cereus; 7.7 $\mathrm{mm}, 8.3 \mathrm{~mm}$ and 8.7 respectively against $S$. typhi; $6.5 \mathrm{~mm}, 8.3 \mathrm{~mm}$ and $9.2 \mathrm{~mm}$ against E. coli. The Ethanolic extract at $30 \mu \mathrm{L} /$ disc, $40 \mu \mathrm{L} /$ disc and $50 \mu \mathrm{L} /$ disc showed $-B$. subtilis were Resistant to all; $9 \mathrm{~mm}, 10 \mathrm{~mm}$ and $11.3 \mathrm{~mm}$ respectively against $B$. cereus; $S$. typhi were Resistant to all; $8 \mathrm{~mm}, 8.3 \mathrm{~mm}$ and $9.8 \mathrm{~mm}$ against $E$. coli (Table 4). 
Table 1. Zones of Inhibition of the methanolic extract and ethanolic extract of Oxalis corniculata at different concentration against four bacterial species.

\begin{tabular}{|c|c|c|c|c|c|c|c|}
\hline \multirow[b]{2}{*}{ Bacterial species } & \multicolumn{3}{|c|}{ Methanolic Extract } & \multicolumn{3}{|c|}{ Ethanolic Extract } & \multirow{2}{*}{ 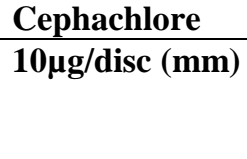 } \\
\hline & $\begin{array}{l}15 \\
\mu \mathrm{L} / \mathrm{disc} \\
(\mathrm{mm})\end{array}$ & $\begin{array}{l}20 \\
\mu \mathrm{L} / \mathrm{disc} \\
(\mathrm{mm})\end{array}$ & $\begin{array}{l}25 \\
\mu \mathrm{L} / \mathrm{disc} \\
(\mathrm{mm})\end{array}$ & $\begin{array}{l}30 \\
\mu \mathrm{L} / \mathrm{disc} \\
(\mathbf{m m})\end{array}$ & $\begin{array}{l}40 \\
\mu \mathrm{L} / \mathrm{disc} \\
(\mathrm{mm})\end{array}$ & $\begin{array}{l}\mathbf{5 0} \\
\mu \mathrm{L} / \mathrm{disc} \\
(\mathrm{mm})\end{array}$ & \\
\hline $\begin{array}{l}\text { Bacillus subtillis } \\
\text { ATCC } 11774\end{array}$ & 6.2 & 7.3 & 9.2 & 7.7 & 8.5 & 9.3 & 19.7 \\
\hline $\begin{array}{l}\text { Bacillus cereus } \\
\text { ATCC } 11778\end{array}$ & $\mathrm{R}$ & $\mathrm{R}$ & $\mathrm{R}$ & 7.5 & 7.8 & 9.2 & $\mathrm{R}$ \\
\hline $\begin{array}{l}\text { Salmonella typhi } \\
\text { ATCC } 14028\end{array}$ & 7 & 8.3 & 9.5 & 7.3 & 9 & 9.7 & 34.7 \\
\hline $\begin{array}{l}\text { E. coli } \\
\text { ATCC } 25923\end{array}$ & 9.2 & 10.2 & 10.5 & 9.8 & 10.7 & 10.8 & 26.7 \\
\hline
\end{tabular}

$\mathbf{R}=$ Resistant

Table 2. Zones of Inhibition of the methanolic extract and ethanolic extract of Centella asiatica at different concentration against four bacterial species.

\begin{tabular}{|c|c|c|c|c|c|c|c|}
\hline \multirow[b]{2}{*}{ Bacterial species } & \multicolumn{2}{|c|}{ Methanolic Extract } & \multicolumn{4}{|c|}{ Ethanolic Extract } & \multirow{2}{*}{$\begin{array}{l}\text { Cephachlore } \\
10 \mu \mathrm{g} / \text { disc }(\mathrm{mm})\end{array}$} \\
\hline & $\begin{array}{l}15 \\
\mu \mathrm{L} / \mathrm{disc} \\
(\mathrm{mm})\end{array}$ & $\begin{array}{l}20 \mu \mathrm{L} / \mathrm{disc} \\
(\mathrm{mm})\end{array}$ & $\begin{array}{l}25 \\
\mu \mathrm{L} / \mathrm{disc} \\
(\mathrm{mm})\end{array}$ & $\begin{array}{l}30 \\
\mu \mathrm{L} / \mathrm{disc} \\
(\mathbf{m m})\end{array}$ & $\begin{array}{l}40 \\
\mu \mathrm{L} / \mathrm{disc} \\
(\mathrm{mm})\end{array}$ & $\begin{array}{l}\mathbf{5 0} \\
\mu \mathrm{L} / \mathrm{disc} \\
(\mathrm{mm}) \\
\end{array}$ & \\
\hline $\begin{array}{l}\text { Bacillus subtillis } \\
\text { ATCC } 11774\end{array}$ & 5.3 & 7.3 & 9.2 & 5.8 & 6.5 & 7.1 & 19.7 \\
\hline $\begin{array}{l}\text { Bacillus cereus } \\
\text { ATCC } 11778\end{array}$ & $\mathrm{R}$ & $\mathrm{R}$ & $\mathrm{R}$ & $\mathrm{R}$ & $\mathrm{R}$ & $\mathrm{R}$ & $\mathrm{R}$ \\
\hline $\begin{array}{l}\text { Salmonella typhi } \\
\text { ATCC } 14028\end{array}$ & 6.2 & 9.3 & 9.7 & 7 & 9.7 & 11 & 34.7 \\
\hline $\begin{array}{l}\text { E. coli } \\
\text { ATCC } 25923\end{array}$ & 5.7 & 7.7 & 8.2 & 6.6 & 7.9 & 9 & 26.7 \\
\hline
\end{tabular}

$\mathbf{R}=$ Resistant

Table 3. Zones of Inhibition of the methanolic extract and ethanolic extract of Phoenix dactylifera at different concentration against four bacterial species.

\begin{tabular}{|c|c|c|c|c|c|c|c|}
\hline \multirow[b]{2}{*}{ Bacterial species } & \multicolumn{3}{|c|}{ Methanolic Extract } & \multicolumn{3}{|c|}{ Ethanolic Extract } & \multirow{2}{*}{$\begin{array}{l}\text { Cephachlore } \\
10 \mu \mathrm{g} / \text { disc }(\mathrm{mm})\end{array}$} \\
\hline & $\begin{array}{l}30 \\
\mu \mathrm{L} / \text { disc } \\
(\mathrm{mm})\end{array}$ & $\begin{array}{l}40 \\
\mu \mathrm{L} / \mathrm{disc} \\
(\mathrm{mm})\end{array}$ & $\begin{array}{l}\mathbf{5 0} \\
\mu \mathrm{L} / \mathrm{disc} \\
(\mathrm{mm})\end{array}$ & $\begin{array}{l}30 \\
\mu \mathrm{L} / \mathrm{disc} \\
(\mathrm{mm})\end{array}$ & $\begin{array}{l}40 \\
\mu \mathrm{L} / \mathrm{disc} \\
(\mathrm{mm})\end{array}$ & $\begin{array}{l}50 \\
\mu \mathrm{L} / \mathrm{disc} \\
(\mathbf{m m})\end{array}$ & \\
\hline $\begin{array}{l}\text { Bacillus subtillis } \\
\text { ATCC } 11774\end{array}$ & $\mathrm{R}$ & $\mathrm{R}$ & $\mathrm{R}$ & $\mathrm{R}$ & $\mathrm{R}$ & $\mathrm{R}$ & 19.7 \\
\hline $\begin{array}{l}\text { Bacillus cereus } \\
\text { ATCC } 11778\end{array}$ & 5.5 & 6 & 6 & 6.2 & 7.1 & 7.6 & $\mathrm{R}$ \\
\hline $\begin{array}{l}\text { Salmonella typhi } \\
\text { ATCC } 14028\end{array}$ & 7.2 & 7.3 & 7.5 & 7.5 & 7.8 & 8.3 & 34.7 \\
\hline $\begin{array}{l}\text { E. coli } \\
\text { ATCC } 25923\end{array}$ & 6.3 & 7.2 & 7.4 & 6.6 & 7.9 & 8.3 & 26.7 \\
\hline
\end{tabular}

$\mathbf{R}=$ Resistant 
Table 4. Zones of Inhibition of the methanolic extract and ethanolic extract of Clitoria ternatea at different concentration against four bacterial species.

\begin{tabular}{|c|c|c|c|c|c|c|c|}
\hline \multirow[b]{2}{*}{ Bacterial species } & \multicolumn{3}{|c|}{ Methanolic Extract } & \multicolumn{3}{|c|}{ Ethanolic Extract } & \multirow{2}{*}{$\begin{array}{l}\text { Cephachlore } \\
10 \mu \mathrm{g} / \text { disc }(\mathrm{mm})\end{array}$} \\
\hline & $\begin{array}{l}15 \\
\mu \mathrm{L} / \mathrm{disc} \\
(\mathrm{mm})\end{array}$ & $\begin{array}{l}20 \\
\mu \mathrm{L} / \text { disc } \\
(\mathbf{m m})\end{array}$ & $\begin{array}{l}25 \\
\mu \mathrm{L} / \mathrm{disc} \\
(\mathrm{mm})\end{array}$ & $\begin{array}{l}30 \\
\mu \mathrm{L} / \mathrm{disc} \\
(\mathrm{mm})\end{array}$ & $\begin{array}{l}40 \\
\mu \mathrm{L} / \mathrm{disc} \\
(\mathrm{mm})\end{array}$ & $\begin{array}{l}\mathbf{5 0} \\
\boldsymbol{\mu} \mathrm{L} / \mathrm{disc} \\
(\mathrm{mm})\end{array}$ & \\
\hline $\begin{array}{l}\text { Bacillus subtillis } \\
\text { ATCC } 11774\end{array}$ & $\mathrm{R}$ & $\mathrm{R}$ & $\mathrm{R}$ & $\mathrm{R}$ & $\mathrm{R}$ & $\mathrm{R}$ & 19.7 \\
\hline $\begin{array}{l}\text { Bacillus cereus } \\
\text { ATCC } 11778\end{array}$ & 6.2 & 8.3 & 8.5 & 9 & 10 & 11.3 & $\mathrm{R}$ \\
\hline $\begin{array}{l}\text { Salmonella typhi } \\
\text { ATCC } 14028\end{array}$ & 7.7 & 8.3 & 8.7 & $\mathrm{R}$ & $\mathrm{R}$ & $\mathrm{R}$ & 34.7 \\
\hline $\begin{array}{l}\text { E. coli } \\
\text { ATCC } 25923\end{array}$ & 6.5 & 8.3 & 9.2 & 8 & 8.3 & 9.8 & 26.7 \\
\hline
\end{tabular}

$\mathbf{R}=$ Resistant

Table 5. Zones of Inhibition of the ethanolic extract and oils of $N$. sativa at different concentration against four bacterial species.

\begin{tabular}{lllll}
\hline Bacterial species & \multicolumn{3}{c}{ Ethanolic Extract } & Oils \\
\cline { 2 - 5 } & $\begin{array}{l}\mathbf{2 0} \boldsymbol{\mu L} / \mathrm{disc} \\
(\mathbf{m m})\end{array}$ & $\begin{array}{l}\mathbf{4 0} \boldsymbol{\mu \mathrm { L } / \mathrm { d } i s c} \\
(\mathbf{m m})\end{array}$ & $\begin{array}{l}\mathbf{2 0} \boldsymbol{\mu L} / \mathrm{disc} \\
(\mathbf{m m})\end{array}$ & $\begin{array}{l}\mathbf{4 0} \boldsymbol{\mu L} / \mathrm{disc} \\
(\mathbf{m m})\end{array}$ \\
\cline { 2 - 5 } $\begin{array}{l}\text { Bacillus cereus } \\
\begin{array}{l}\text { ATCC 11778 } \\
\text { Bacillus subtillis }\end{array}\end{array}$ & 16 & 19.5 & 16 & 17 \\
$\begin{array}{l}\text { ATCC 11774 } \\
\text { Pseudomonas aeruginosa }\end{array}$ & 19 & 27 & 16 & 26 \\
$\begin{array}{l}\text { Salmonella typhi } \\
\text { ATCC 14028 }\end{array}$ & 23 & 26.5 & 32 & 35 \\
\hline
\end{tabular}

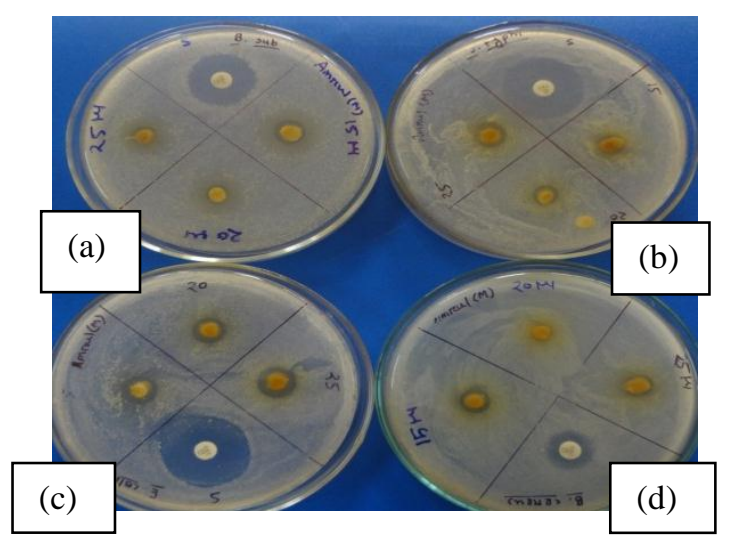

Figure 1. Antibacterial activity of methanolic extract of Oxalis corniculata against all four bacteria (a) $B$. subtilis, (b) S. typhi, (c) E. coli and (d) B. cereus

\subsection{Determination of antimicrobial activity of $N$. sativa}

Zone of inhibition of the ethanolic extract at $20 \mu \mathrm{L} / \mathrm{disc}$ and $40 \mu \mathrm{L} / \mathrm{disc}$ are $-16 \mathrm{~mm}$ and $19.5 \mathrm{~mm}$ respectively against $B$. cereus; $19 \mathrm{~mm}$ and $27 \mathrm{~mm}$ respectively against $B$. subtilis; $23 \mathrm{~mm}$ and $26.5 \mathrm{~mm}$ respectively against $P$. aeruginosa; $16 \mathrm{~mm}$ and $19.5 \mathrm{~mm}$ against $S$. typhi. The Oil extract at $20 \mu \mathrm{L} / \mathrm{disc}$ and $40 \mu \mathrm{L} / \mathrm{disc}$ showed- 16 $\mathrm{mm}$ and $17 \mathrm{~mm}$ respectively against $B$. cereus; $16 \mathrm{~mm}$ and $26 \mathrm{~mm}$ respectively against $B$. subtilis; $32 \mathrm{~mm}$ and $35 \mathrm{~mm}$ respectively against $P$. aeruginosa; $21.5 \mathrm{~mm}$ and $24.5 \mathrm{~mm}$ against $S$. typhi (Table 5).

\section{Discussion}

Among the Centella asiatica, Oxalis corniculata, Phoenix dactylifera \& Clitoria ternatea extracts, ethanol extract of Oxalis corniculata showed activity against all the four isolates, it also showed a higher activity on all the three isolates except Bacillus cereus. Higher activity to Bacillus cereus was obtained by the ethanol extract 
of Clitoria ternatea. The leaf extracts of $C$. asiatica and $O$. corniculata showed significant inhibitory activities as compared to Phoenix dactylifera \& Clitoria ternatea fruit and seed extracts. The presence of phytoconstituents in the leaf extracts may be responsible for the antibacterial activity of the plant (Marjorie, 1999). Phytochemical analysis of all the solvent extracts revealed the presence of carbohydrates and glycosides, phytosterols, phenolic compounds/tannins, flavonoids, proteins and aminoacids and volatile oils are present in ethanolic and methanolic extracts of Oxalis corniculata (Raghavendra et al., 2006).

Methanolic and Ethanolic extract of Clitoria ternatea and Phoenix dactylifera showed higher antibacterial activity to gram negative bacteria compared to gram positive bacteria. Two important gram negative pathogens viz., E. coli and S. typhi are highly susceptible to methanolic extract of Clitoria ternatea seed and Phoenix dactylifera fruit extract. Both methanolic and ethanolic extract of Oxalis corniculata showed higher antibacterial activity to both gram negative and gram positive bacteria and indicated a broad spectrum of activity except gram positive bacteria Bacillus cereus. Methanolic and ethanolic extract of Clitoria ternatea differ in the resistence of Salmonella typhi against ethanolic extract. The resistence may be occurred by this bacterial strain may possess resistant mechanism or use of lesser than of minimum inhibitory concentration of the extract. The variation of antibacterial activities of the different extracts can be rationalized in terms of the polarity of the solvents used, polarity of the compounds being extracted from each solvent and in addition to their extrinsic bioactivity and by their ability to dissolve or diffuse in the media used in the assay (Anjana et al., 2009). Furthermore, it is seen that the diameter of the zones of inhibition of the extracts increases as their concentrations increases, with exception of those shows no zone of inhibition.

In this study, we also investigated the antibacterial effects of ethanolic seed extracts and oils of Nigella sativa on four bacterial strains. The antibacterial activities of ethanolic extract and oils of Nigella sativa against four bacteria are shown in Table 4. Antibacterial effects of the tested ethanolic extract and oils concentrations showed variations against the bacterial strains. Pseudomonas aeruginosa shows best inhibition for both the ethanolic extract and oils at different concentration. Salmonella typhi shows the same degree of inhibition for ethanolic extract as Bacillus cereus, but greater inhibition for oils. Of all the bacteria, Pseudomonas aeruginosa was the most sensitive bacteria against all of the concentrations of ethanolic extract and oils, while Bacillus cereus was the most resistant bacteria. Generally, the oils of Nigella sativa sample had higher antibacterial activity against bacteria than ethanolic extract. Many components of Nigella sativa were characterised by Burits and Bucar (2000) using GC-MS, but the major ones were thymoquinone, p-cymene and carvacrol. All of these compounds had antibacterial effect (Ali and Blunden, 2003). Hence, the antibacterial effects of our samples may be closely related to their high percentage of these compounds.

Salmonella typhi the most dangerous gram negative human pathogen is sensitive to all the plant and plant derived extracts studied in this research. Only except the ethanolic extract of Clitoria ternatea, all the extracts produced zone of inhibition. Among them N. sativa produced largest zone of inhibition. All the methanolic extracts were inhibitor of $S$. typhi. Not only $S$. typhi but also all the isolates showed inhibitory activity against gram negative pathogen $E$. coli. Therefore it can be stated that the study extracts are more active against gram negative bacteria and could possibly be used against other gram negative pathogens.

\section{Conclusions}

The results of the present study along with early reports concluded that the extracts have potent antibacterial activity against the clinical human pathogens Salmonella typhi and E. coli. The present investigation data on antibacterial potency of Centella asiatica, Oxalis corniculata, Phoenix dactylifera, Clitoria ternatea \& Nigella sativa are helpful to design further study for synthesis of novel antibacterial agent. Along with this, the oil of Nigella sativa may be used in food as a preservative.

\section{Conflict of interest}

None to declare.

\section{References}

Ahmed L, Z Mohammed and F Mohammed, 1998. Screening of some Indian medicinal plants for their antimicrobial properties. J. Ethnopharmacol., 62: 183-193.

Akgul A, 1989. Antimicrobial activity of black cumin (Nigella sativa L.) essential oil. J. Fac. Pharm. Gazi., 6: 63-68.

Ali BH and G Blunden, 2003. Pharmacological and toxicological properties of Nigella sativa. Phyt. Res., 17: 299-305. 
Anjana S, V Rani and R Podmini, 2009. Antibacterial activity of some medicinal plants used by tribal against UTI causing pathogens. World. Appl. Sci. J., 7: 332-339.

Babu S, S Satish, DC Mohana, MP Raghavendra and KA Raveesha, 2007. Antibacterial evaluation and phytochemical analysis of some Iranian medicinal plants against pathogenic Xanthomonas pathovars. J. Agri. Tech., 3: 307-316.

Bauer AW, WMM Kirby, JC Sherris and M Turck, 1966. Antibiotic susceptibility testing by a standardized single disc method. Am. J. Clin. Pathol., 45: 493-496.

Burits M and F Bucar, 2000. Antioxidant activity of Nigella sativa essential oil. Phyt. Res., 14: 323-328.

Cox PA and MJ Balick, 1994. The ethnobotanical approach to drug discovery. SciAm., 270: 60-65.

Essawi $\mathrm{T}$ and M Srour, 2000. Screening of some Palestinian medicinal plants for antibacterial activity. J. Ethnopharmacol., 70: 343-349

Farrag HA, ZEM El-Bazza, MED El-Fouly and SYM El-Tablawy, 2000. Effect of gamma radiation on the bacterial flora of Nigella sativa seeds and its oil constituents. Gr. Y. Ace., 50: 195-207.

Ghani A, 1998. Medicinal Plants of Bangladesh: Chemical Constituents and Uses. Asiatic Society of Bangladesh, Dhaka.

Hanafy MSM and ME Hatem, 1991. Studies on the antimicrobial activity of (black cumin). J. Ethnopharmacol., 34: 275-278.

Khan MAU, MK Ashfaq, HS Zuberi, MS Mahmood and AH Gilani, 2003. The in vivo antifungal activity of the aqueous extract from Nigella sativa seeds. Phyt. Res., 17: 183-186.

Kumar A, RK Mishra, S Srivastava, AK Tiwari, A Pandey, AC Shukla and A Dikshit, 2011. Role of phylogenetic analysis for antbacterial ativity of essential oil of Trachyspermum Ammi L. against water borne pathogens. Adv. Environ. Biol., 5: 1271-1278.

Lino A and O Deograios, 2006. The in-vitro antibacterial activity of Annona senegalensis, Seuridcca longipendiculata and Steanotaenia araliacea- Ugandan medicinal plants. Afr. Health Sci., 6: 31-35.

Okemo PO, HP Bais and JM Vivanco, 2003. In vitro activities of Maesa lanceolata extracts against fungal plant pathogens. Fitoterapia., 74: 312-316.

Ozcan M (1998) Note: Inhibitory effects of spice extracts on the growth of Aspergillus parasiticus NRRL2999 strain. Z. Lebensm. Unters. Forsch., 207: 253-255.

Raghavendra MP, S Satish and KA Raveesha, 2006. Phytochemical analysis and antibacterial activity of Oxalis corniculata; a known medicinal plant. mySCIENCE., 1: 72-78.

Shariff N, MS Sudarshana, S Umesha and P Hariprasad, 2006. Antimicrobial activity of Rauvolfia tetraphylla and Physalis minima leaf and callus extracts. Afr. J. Biotechnol., 5: 946-950.

Williams RJ and DL Heyamnn, 1998. Containment of antibiotic resistance. Sci., 279: 1153-1154.

Zampini IC, S Cuello and MR Alberto, 2009. Antimicrobial activity of selected plant species from the Argentine puna against sensitive and multiresistant bacteria. J. Ethnopharmacol., 124: 499-505. 